\title{
KEANEKARAGAMAN BURUNG PADA ZONA PENYANGGA TAMAN NASIONAL GUNUNG CIREMAI
}

\author{
Cucu Nurmaeti ${ }^{1)}$, Zaenal Abidin ${ }^{2)}$, Agus Prianto ${ }^{3)}$ \\ ${ }^{1}$ Mahasiswa Program Studi Pendidikan Biologi FKIP, Universitas Kuningan \\ Email : cucunurmaeti57@gmail.com \\ ${ }^{23}$ Dosen Program Studi Pendidikan Biologi FKIP, Universitas Kuningan \\ Email : zaenal.abidin@uniku.ac.id \\ Email : agus.prianto@uniku.ac.id
}

APA Citation: Nurmaeti, C., Abidin, Z., \& Prianto, A. (2018). Keanekaragaman Burung Pada Zona Penyangga Taman Nasional Gunung Ciremai. Quagga: Jurnal Pendidikan dan Biologi, 10(2), 52-57. doi: 10.25134/quagga.v10i2..

Received: 20-07-2018

Accepted: $31-07-2018$

Published: 31-07-2018

\begin{abstract}
Abstrak: Penelitian tentang keanekaragaman burung pada zona penyangga Taman Nasional gunung Ciremai ini bertujuan mengetahui keanekaragaman burung, dan hubungan vegetasi tumbuhan dengan keankeragaman burung pada zona penyangga taman nasional gunung ciremai. Penelitian ini dilaksanakan pada bulan Mei 2017 bertempat di Kebun Raya Kuningan. Pengambilan data sampel dilakukan sebanyak 4 kali pengulangan dengan waktu pengamatan yaitu pagi 06.00-09.00 WIB dan sore 16.00-18.00 WIB. Metode yang digunakan pada penelitian ini adalah metode survey dengan metode pengambilan data yaitu metode IPA (Index Ponctualle de'Abondance). Data yang diperoleh dihitung dengan menggunakan indeks keanekaragaman Shannon-Wiener dan uji regresi linier sederhana. Berdasarkan hasil penelitian ditemukan 14 Famili dan 22 spesies burung, dan berdasarkan hasil analisis uji regresi linier sederhana menunjukan bahwa tumbuhan berpengaruh terhadap keanekargaman burung di Kebun Raya Kuningan.
\end{abstract}

Kata Kunci : Burung, Zona penyangga, Taman Nasional Gunung Ciremai

Abstract: This research on bird diversity in the buffer zone of Ciremai Mountain National Park aims to determine bird diversity, and the relationship between plant vegetation and bird diversity in the buffer zone of Gunung Ciremai National Park. This research was conducted in May 2017 at the Kuningan Botanical Garden. Retrieval of sample data is carried out as many as 4 repetitions with observation time, namely morning 06.0009.00 WIB and afternoon 16.00-18.00 WIB. The method used in this study is a survey method with data collection methods, namely the IPA method (Index Ponctualle de'Abondance). The data obtained was calculated using the Shannon-Wiener diversity index and a simple linear regression test. Based on the results of the study found 14 families and 22 species of birds, and based on the results of a simple linear regression analysis showed that plants affect the bird diversity in the Kuningan Botanical Gardens.

Keywords: Birds, buffer zones, Gunung Ciremai National Park

\section{PENDAHULUAN}

Keanekaragaman burung yang ada pada suatu wilayah atau habitat menjadi salah satu acuan dalam pengelolaan sumber daya hayati. Burung berperan penting dalam kehidupan di alam, burung mengendalikan populasi serangga, membantu penyerbukan dan penyebaran biji. Sesuai dengan pernyataan Hadinoto, dkk (2012) di samping berperan dalam keseimbangan ekosistem burung dapat menjadi indikator perubahan lingkungan. Dan menurut Rusmendro (2009) sebagai salah satu komponen ekosistem, burung mempunyai hubungan timbal balik dan saling tergantung dengan lingkungannya. Atas dasar peran dan manfaat ini maka kehadiran burung dalam suatu ekosistem perlu dipertahankan.

Dengan demikian burung merupakan indikator penting dalam ekosistem dan ekosistem ini merupakan suatu bagian yang menjadi sorotan penting dalam konservasi. Sesuai dengan pernyataan Tony Whitten et.al (1996), bahwa konservasi merupakan suatu proses dimana pemeliharaan ekosistem, pengelolaan keragaman hayati, pengelolaan lingkungan, pendidikan dan pemecahan masalah, semuanya terintegrasi dalam kawasan tertentu. Yang bertujuan memelihara ekosistem yang cukup luas untuk kelangsungan proses-proses alami dengan sedikit mungkin melibatkan campur tangan manusia, sambil memelihara habitat sebanyak mungkin 
Quagga: Jurnal Pendidikan dan Biologi

Volume 10, Nomor 2, Juli 2018

dan dengan demikian memelihara keragaman struktur dan taksonominya.

Hal ini sejalan dengan pemerintah Kabupaten Kuningan yang membangun kawasan konservasi, yakni Taman Nasional Gunung Ciremai dan Kebun Raya Kuningan, seperti yang tertulis dalam Peraturan Daerah Kabupaten Kuningan Nomor 26 Tahun 2011 Bab IV pasal 6 "mengembangkan KRK sebagai kawasan konservasi ex-situ". Kawasan Kebun Raya berdampingan dengan Taman Nasional Gunung Ciremai, yang hampir separuh kawasannya berada di Kabupaten Kuningan. Kawasan konservasi ini dibagi menjadi beberapa zona yaitu diantaranya zona inti, dan zona penyangga. Begitupun dengan kawasan lahan konservasi yang diusung oleh pemerintah kabupaten Kuningan yakni Taman Nasional Gunung Ciremai sebagai zona inti, dan Kebun Raya Kuningan sebagai zona penyangga yang bertempat di Kecamatan Pasawahan Desa Padabeunghar yang merupakan daerah penyangga Taman Nasional Gunung Ciremai (BTNGC, 2012).

Kebun Raya Kuningan merupakan kawasan daerah penyangga sekitar kawasan taman nasional, karena Kebun Raya Kuningan memiliki struktur vegetasi menyerupai hutan alam yang merupakan habitat satwaliar untuk burung dan mamalia mencari pakan. Menurut M. Bismark dan Reny Sawitri (2007) daerah penyangga atau buffer zone ini bermanfaat bagi konservasi tanah dan air, biodiversitas flora melalui konservasi eks-situ dan habitat satwaliar termasuk burung.

Dengan demikian berdasarkan latar belakang tersebut diperlukan penelitian untuk mengetahui keanekaragaman jenis burung pada zona penyangga Taman Nasional Gunung.

\section{METODOLOGI PENELITIAN}

Penelitian dilakukan di Kebun raya Kuningan yang merupakan bagian dari wilayah zona penyangga Taman Nasional Gunung Ciremai, penelitian ini dilakukan selama bulan Mei dengan menggunakan empat kali pengulangan. Waktu pengamatan dilakukan pada pagi jam 06.00-09.00 WIB dan sore hari jam 16.00-18.00 WIB, dan dilaksanakan 2 kali dalam setiap pengamatan. Dan lokasi pengambilan data di bagi menjadi tiga plot yaitu plot I pusat informasi/kantor Kebun Raya Kuningan, plot II ekosistem terbuka (danau), dan plot III perbatasan antara zona inti dan zona buffer (hutan).
p-ISSN 1907-3089, e-ISSN2651-5869

https://journal.uniku.ac.id/index.php/quagga

Adapun metode dalam penelitian ini menggunakan metode survey, dan untuk pengambilan data populasi burung digunakan metode IPA (Index Ponctualle de'Abondance) merupakan metode yang digunakan untuk mencatat populasi burung secara kuantitatif yaitu pencacahan atau sensus (Fachrul, 2007). Dan untuk pengambilan data vegetasi pada setiap plot menggunakan metode line transek.

Adapun analisis data burung menggunakan : Indeks Keanekaragaman Shannon-Wiener seperti yang di acu oleh Fachrul (2007):

$$
\mathbf{H}^{\prime}=-\sum \text { PilnPi }
$$

Keterangan :

$\mathrm{H}^{\prime}$ = indeks keanekaragaman jenis

$\mathrm{Pi}=$ proporsi nilai penting

$\mathrm{ln}=$ logaritma natural

Klasifikasi nilai indeks keanekaragaman Shannon-Wiener

$<1=$ Keanekargaman jenis rendah

1-3 = Kenekaragaman jenis sedang

$>3=$ Keanekaragaman jenis tinggi

Sedangkan analisis data vegetasi menggunakan :

Kerapatan

$K=\frac{j u m l a h \text { individu suatu jenis }}{\text { luas unit contoh }}$

$K R=\frac{\text { kerapatan suatu jenis }}{\text { kerapatan total jenis }} \times 100 \%$

Frekuensi

$F=\frac{\text { jumlah plot suatu jenis }}{\text { total plot }}$

$F R=\frac{\text { frekuensi suatujenis }}{\text { total frekuensi }} \times 100 \%$

Dominansi

$D=\frac{\text { luas bidang dasar suatu jenis }}{\text { luas unit contoh }}$

$D R=\frac{\text { dominansi suatu jenis }}{\text { dominansi seluruh jenis }} \times 100 \%$

Indeks Nilai Penting (INP)

$I N P=K R+D R+F R$

Dan untuk analisis data untuk mengkaji pengaruh hubungan indeks nilai penting tumbuhan terhadap indeks keanekaragaman burung menggunakan analisis data uji regresi linier sederhana 
Quagga: Jurnal Pendidikan dan Biologi

Volume 10, Nomor 2, Juli 2018

\section{HASIL DAN PEMBAHASAN}

\section{Hasil}

Keanekaragaman Jenis Burung

Berdasarkan hasil pengamatan di lapangan dan identifikasi, jenis burung yang ditemukan di semua plot sebanyak 22 jenis burung, dengan total perjumpaan 872 individu. Adapun hasil yang didapat pada plot I diperoleh jumlah spesies sebanyak 14 spesies, plot II sebanyak 19 spesies, dan plot III sebanyak 19 spesies. Sementara
p-ISSN 1907-3089, e-ISSN2651-5869

https://journal.uniku.ac.id/index.php/quagga

untuk jumlah individu yang diperoleh dari plot I yaitu sebanyak 237 individu, plot II sebanyak 306 individu, dan plot III sebanyak 329 individu. Dari ketiga plot untuk jumlah spesies tertinggi terdapat pada plot II dan III yaitu 19 spesies, sementara untuk jumlah individu tertinggi terdapat pada plot III yaitu 329.

Adapun jenis-jenis burung yang didapatkan dari semua plot dapat dilihat pada tabel 1 .

Tabel 1. Jenis Burung yang ditemukan di Tiga Plot Pengamatan

\begin{tabular}{cllccc}
\hline No. & \multicolumn{1}{c}{ Nama Jenis } & \multicolumn{1}{c}{ Nama Ilmiah } & Plot I & Plot II & Plot III \\
\hline 1 & Elang hitam & Ictinaetus malayensis & - & 3 & - \\
\hline 2 & Sikep madu asia & Pernis ptilorhynchus & - & - & 1 \\
\hline 3 & Cipoh kacat & Aegithina tiphia & 1 & 6 & 16 \\
\hline 4 & Cekakak jawa & Halcyon pileata & 9 & 8 & 8 \\
\hline 5 & Cekakak sungai & Todirhampus chloris & 5 & 3 & - \\
\hline 6 & Walet linci & Collocalia linchi & 98 & 178 & 136 \\
\hline 7 & Sepah Kecil & Pericrocotus & 2 & 1 & 2 \\
\hline 8 & Perkutut jawa & Geopelia striata & - & - & 1 \\
\hline 9 & Tekukur biasa & Streptopelia chinensis & 14 & 4 & 17 \\
\hline 10 & Walik kembang & Ptilinopus melanospilus & - & 1 & - \\
\hline 11 & Bubut alang-alang & Centropus bengalensis & 4 & 8 & 15 \\
\hline 12 & Srigunting Bukit & Dicrurus hottentottus & 1 & 3 & 2 \\
\hline 13 & Srigunting kelabu & Dicrurus leucophaeus & - & 1 & 2 \\
\hline 14 & Bondol peking & Lonchura punctulata & 34 & 47 & 34 \\
\hline 15 & Burung madu sriganti & Nectarinia jugularis & 3 & - & 4 \\
\hline 16 & Puyuh batu & Coturnix chinensis & - & 1 & 1 \\
\hline 17 & Cucak kutilang & Pycnonotus aurigaster & 50 & 35 & 69 \\
\hline 18 & Merbah cerukcuk & Pycnonotuc goiavier & 16 & 7 & 21 \\
\hline 19 & Cici Padi & Cisticola juncidis & 8 & 15 & 16 \\
\hline 20 & Cinenen kelabu & Orthotomus ruficeps & 8 & 7 & 4 \\
\hline 21 & Kerak kerbau & Acridotheres javanicus & - & 2 & 6 \\
\hline 22 & Uncal buau & Macropygia emiliana & - & 2 & 8 \\
\hline & & Jumlah & $\mathbf{2 3 7}$ & $\mathbf{3 0 6}$ & $\mathbf{3 2 9}$ \\
\hline & & & & \\
\hline & & & 7 & 2 \\
\hline
\end{tabular}

Perhitungan data jenis burung yang diperoleh dinyatakan dalam bentuk indeks biologi. Indeks biologi yang digunakan dalam penelitian ini yaitu indeks keanekaragaman. Berdasarkan hasil pengolahan data, diperoleh indeks keanekaragaman $\left(\mathrm{H}^{\prime}\right)$ yang berbeda antar plot. Dimana indeks keanekaragaman tertinggi terdapat pada plot III dengan nilai 2,09. Dan untuk indeks keanekaragamaan terendah terdapat pada plot II dengan nilai 1,715 .
Vegetasi

Tumbuhan yang ditemukan pada plot pengamatan I jenis yang mendominasi yaitu Casiatimorensis dengan INP 102,6\%, Lagerstroemia speciosa dengan INP 39,194\% dan Durio zibethinus dengan nilai INP 24,351\%. Sementara untuk plot pengamatan II jenis tumbuhan yang mendominasi adalah Elaeocarpus glandiporus dengan INP 38,852\%, Ingalorina dengan INP $35,666 \%$ dan Durio 
Quagga: Jurnal Pendidikan dan Biologi

Volume 10, Nomor 2, Juli 2018

zibethinus dengan INP 30,511\%. Dan untuk tumbuhan yang ditemukan pada plot pengamatan III jenis yang mendominasi yaitu Gnetum gnemon dengan INP 61,057\%, Swietenia mahagoni dengan nilai INP 54,424\% dan Cassia siamea dengan INP 37,153\%.

Hubungan Indeks Niali Penting Tumbuhan dengan Indeks Keankeragaman Burung di Semua Plot

Hubungan antara Indeks Nilai Penting (INP) tumbuhan dengan Indeks Keanekaragaman burung dihitung menggunakan analisis uji Regresi Linear. Hasil uji regresi linear antara INP dengan indeks keankeragaman burung pada ke tiga plot menunjukan hasil perhitungan $t$ hitung sebesar 5,196, $\mathrm{t}$ tabel sebesar 12,706, dan signifikansi 0,121 .

\section{Pembahasan}

Berdasarkan hasil penelitian mengenai keanekaragaman burung antar plot di Kebun Raya Kuningan dapat diketahui bahwa di setiap plot didominasi oleh spesies yang sama, yaitu plot I, II dan III didominasi oleh Collocalia linchi, Lonchura punctulata dan Pycnonotus aurigaster. Kesamaan spesies yang mendominasi di setiap plot dikarenakan jenis vegetasi yang beragam pada ketiga plot dan indeks nilai penting vegetasi dari ketiga plot memiliki nilai yang sama, hal ini sesuai dengan pernyataan Hadinoto, dkk (2012) bahwa suatu jenis burung yang mendominasi suatu lokasi didukung oleh kondisi habitat yang cukup memadai bagi jenis tersebut terutama dalam ketersedian makanan. Selain itu menurut MacKinnon, et.all (2010) Collocalia linchi ini merupakan salah satu burung yang umum terdapat di semua ketinggian, begitupun dengan spesies Lonchura punctulata dikarenakan penyebarannya luas sampai ketinggian $1.800 \mathrm{~m}$ dan Pycnonotus aurigaster juga merupakan spesies burung yang penyebarannya paling luas dan merupakan spesies yang umum ditemui sampai ketinggian $1.600 \mathrm{~m}$.

Indeks keanekaragaman burung pada semua plot termasuk kedalam kategori sedang yaitu $1 \leq$ $\mathrm{H}^{\prime} \leq 3$, seperti pada Gambar 1. berikut ini :
p-ISSN 1907-3089, e-ISSN2651-5869

https://journal.uniku.ac.id/index.php/quagga

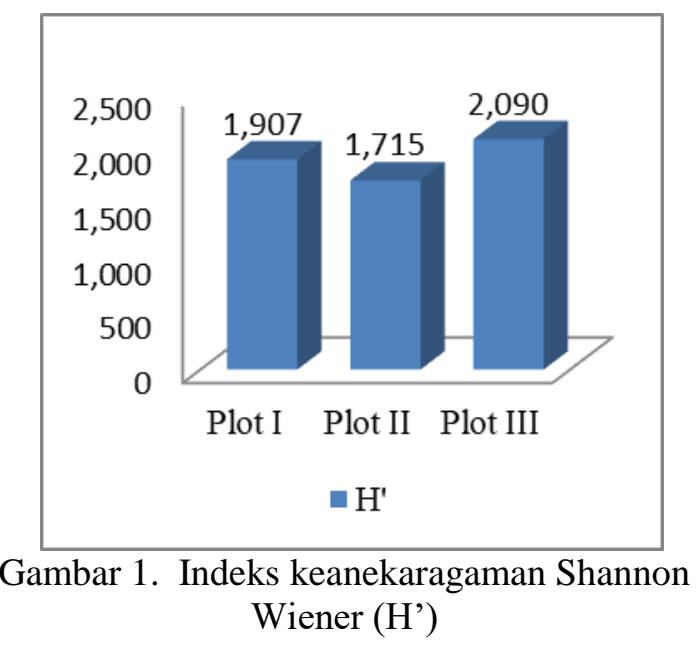

Lokasi penelitian I/plot I berada pada ketinggian $542 \mathrm{dpl}$, jumlah spesies yang teridentifikasi yaitu 11 famili 14 spesies dan 237 indivdu. Plot I merupakan plot dengan jumlah spesies dan nilai indeks keanekaragaman rendah di bandingkan plot III, hal ini dikarenakan lokasi pengamatan plot I ini merupakan area kantor Kebun Raya Kuningan yang notabene pada area ini banyak aktivitas manusia sehingga memungkinkan kurang aman bagi burung, hal ini sesuai dengan pernyataan Jarulis \{(2005) dalam Hadinoto $d k k$. (2012)\} bahwa kehadiran jenis burung kemungkinan disebabkan oleh perbedaan jenis tumbuhan, tingkat kenyamanan dan habitat pendukung yang berdekatan, selanjutnya faktor keamanan dari berbagai bentuk gangguan, struktur dan komposisi jenis vegetasi dan luas lokasi dapat mempengaruhi jumlah jenis burung pada suatu kawasan. Namun apabila dibandingkan dengan plot II, plot I lebih tinggi nilai keanekaragaman burungnya dikarenakan pada plot I ini merupakan lokasi tanaman budidaya yang beragam, sesuai dengan pernyataan Dewi \{(2007) dalam Hadinoto, $d k k$. (2012)\} bahwa habitat yang memiliki jenis vegetasi yang beragam akan menyediakan lebih banyak jenis pakan, sehingga pilihan pakan bagi burung akan lebih banyak. Sehingga dengan demikian burung yang mencari makan di plot I ini pun lebih beragam.

Lokasi penelitian plot II berada pada ketinggian $572 \mathrm{dpl}$, memiliki jumlah burung yang teridentifikasi yaitu 13 famili 19 spesies (Gambar 1) dan 306 individu. Plot II ini merupakan plot habitat ekosistem terbuka atau danau yang memiliki nilai indeks keanekaragman burung yang paling rendah dibandingkan plot I dan plot III. Hal ini berbeda dengan penelitian yang dilakukan oleh Tamnge F (2013) bahwa 
habitat danau merupakan daerah peralihan atau daerah lalu lalang burung sehingga jenis burung yang ditemukan lebih banyak jika dibandingkan dengan habitat lainnya. Hal tersebut dikarenakan plot II ini merupakan lokasi yang berdampingan langsung dengan jalan utama Kebun Raya Kuningan yang selalu dilalui oleh kendaraankendaraan besar yang sedang melakukan proyek pembuatan Situ Lurah, sesuia dengan pernyataan Sujatnika et al. \{(1995) dalam Tamnge F. (2013) \} bahwa meningkatnya tekanan terhadap hidupan liar dan ekosistem alami antara lain disebabkan oleh terus meningkatnya jumlah penduduk, ketidakpastian tata guna dan pengelolaan lahan, dan kebijakan ekonomi serta pembangunan.

Lokasi penelitian plot III berada $621 \mathrm{dpl}$, memiliki jumlah burung yang teridentifikasi paling banyak yaitu 15 famili 19 spesies (Gambar 1) dan 329 individu. Plot III ini merupakan plot yang memiliki nilai keanekaragaman paling tinggi dibandingkan dengan plot lainnya, hal ini dikarenakan plot III ini merupakan lokasi yang berbatasan langsung dengan zona inti yaitu Taman Nasional Gunung Ciremai, lokasi plot III ini juga bisa disebut sebagai daerah peralihan dimana vegetasi pada plot ini merupakan vegetasi alami hutan yang berada pada area Taman Nasional Gunung Ciremai dan vegetasi buatan yaitu tanaman yang sengaja ditanam oleh pihak Kebun Raya Kuningan dan atau tumbuhan yang sudah ada sebelumnya, karena mengingat sebelumnya kawasan Kebun Raya Kuningan ini merupakan area perkebunan PT. HGU sehingga memungkin jenis burung yang mencari makan pada plot ini pun lebih beragam, hal ini sesuai dengan pernyataan Sawitri R et.all (2007) bahwa daerah ecotone atau peralihan antara hutan dengan lokasi perkebunan mengundang burung datang untuk mencari pakan karena di lokasi ini terdapat tumbuhan yang menyediakan pakan, dan menurut Widodo \{(2009) dalam Nugroho et.al (2013) \}bahwa habitat yang kondisinya baik dan jauh dari gangguan manusia, memungkinkan memiliki jenis burung yang banyak.

Hal ini berarti bahwa jenis burung yang berada pada ke tiga plot pengamatan hampir sama, dikarenakan ke tiga lokasi pengamatan berada pada ketinggian yang tidak jauh berbeda sehingga tidak ada barier atau penghalang bagi burung untuk melakukan aktifitas terbang yang didukung oleh kemampuan burung yang mampu terbang berkilo-kilo meter tanpa henti, sesuai dengan pernyataan Alikodra (2002) dan
Syafrudin (2011) bahwa burung merupakan kelompok satwaliar yang paling merata penyebarannya, ini disebabkan karena kemampuan terbang yang dimilikinya.

Selain itu hal tersebut juga di dukung oleh hasil Indeks Nilai Penting tumbuhan ketiga plot tidak ada perbedaan yang signifikan antar plot dalam hal rata-rata indeks nilai penting tumbuhan. Dimana tumbuhan yang terdapat pada ke tiga plot pengamatan merupakan jenis-jenis tumbuhan yang termasuk kedalam beberapa family yang menyediakan sumber pakan bagi burung yaitu family Moraceae, Euphorbiaceae, Sterculiaceae, Anacardiaceae, Myrtaceae, Malvaceae, Apocynaceae, Phyllantaceae sebagai family pengahasil buah. Dan family Fabaceae, Myrtaceae sebagai penghasil bunga (madu, nektar, pollen). Sesuai dengan pernyataan Bishop, et.al (2005) banyak kategori guild atau sumber pakan di dalam suatu tipe habitat menunjukan banyaknya ketersediaan sumberdaya yang mendukung kehidupan burung di dalamnya dan juga menunjukan kualitas lingkungan yang baik.

\section{SIMPULAN}

Dari hasil penelitian mengenai keanekaragaman burung yang dilakukan di Kebun Raya Kuningan, burung yang ditemukan pada ke tiga plot sebanyak 22 jenis burung, 16 famili dengan total perjumpaan 872 individu. Dan berdasarkan hasil penelitian ketiga plot memiliki keanekaragaman burung dalam kategori sedang, serta tumbuhan berpengaruh terhadap keanekargaman burung di zona penyangga Taman Nasional Gunung Ciremai.

\section{REFERENSI}

Alikodra, H. S. 2002. Dasar-Dasar Pembinaan Marga Satwa. Fakultas Kehutanan Institut Pertanian Bogor. Bogor.

Bishop JA, WL Myers. 2005. Associations between avian functional guild response and regional landscape properties for conservation planning. Ecological Indicators 5:33-48.

Bismark, M. dan Reny Sawitri. 2007. Pengembangan Dan Pengelolaan Daerah Penyangga Kawasan Konservasi. Prosiding Ekspose Hasil-Hasil Penelitian. Vol. IV No. 5 : 467-483, 2007

Fachrul, Melati Ferianita. 2007. Metode Sampling Bioekologi. Jakarta : Bumi Aksara. 
Quagga: Jurnal Pendidikan dan Biologi

Volume 10, Nomor 2, Juli 2018
p-ISSN 1907-3089, e-ISSN2651-5869

https://journal.uniku.ac.id/index.php/quagga

Hadinoto, Mulyadi, A., Siregar, YI. 2012. Keanekaragaman Jenis Burung Di Hutan Kota Pekanbaru. Jurnal lingkungan,6 (1): 25-42.

MacKinnon J, Phillips K, Van Balen B. 2010. Seri Panduan Lapangan Burung-Burung Di Sumatera, Jawa, Bali dan Kalimantan. Bogor : Birdlife International-Indonesia Program-Pusat Penelitian dan Pengembangan Biologi LIPI.

Nugroho, Mikhael Satrio et.al. 2013. Keanekaragaman Jenis Burung Pada Areal Dongi-Dongi Di Kawasan Taman Nasional Lore Lindu. Volume 1, Nomor 1

Rusmendro, H. 2009. Perbandingan Keanekaragaman Burung Pada Pagi Dan Sore Hari di Empat Tipe Habitat Di wilayah Pangandaran, Jawa Barat. VIS VITALIS, Vol. 02 No. 1.

Sawitri, R et.al. 2007. Habitat Dan Populasi Burung Di Taman Nasional Gunung Ciremai, Kabupaten Kuningan. Pusat Litbang Hutan dan Konservasi Alam

Syafrudin, D. 2011. Keanekaragaman Jenis Burung Pada Beberapa Tipe Habitat di Tambling Wildlife Nature Conservation (Twnc), Taman Nasional Bukit Barisan Selatan Lampung [Skripsi]. Departemen Konservasi Sumberdaya Hutan dan Ekowisata Fakultas Kehutanan Institut Pertanian Bogor. Bogor.

Tamnge, Fadila. 2013. Keanekaragaman Jenis Burung Pada Beberapa Tipe Habitat Di Pulau Ternate [skripsi]. Bogor : Fakultas Kehutanan, Institut Pertanian Bogor.

Whitten, Tony et.al. 1996. Ekologi Jawa Dan Bali. Jakarta: Prenhallindo. 